\title{
IMMUNOHISTOCHEMISTRY OF GRELINPOSITIVE CELLS IN THE PANCREAS ISLETS OF THE RAT
}

\author{
I. Valkova' ${ }^{1}$, S. Hamza ${ }^{1}$ J. Ananiev ${ }^{2}$, M. Gulubova ${ }^{2}$ \\ ${ }^{1}$ Department of Anatomy, Faculty of Medicine, Trakia University, Stara Zagora, Bulgaria \\ ${ }^{2}$ Department of General and Clinical Pathology, Faculty of Medicine, Trakia University, \\ Stara Zagora, Bulgaria
}

\begin{abstract}
After the discovery of the hormone ghrelin research on it is intensified in recent years. They are mainly clinical researches or studying of its physiological action. Fewer morphological experiments therefore histochemical expression of the cells that produce it, are relatively rare. The purpose of this study was by immunohistochemical methods to localize grelin-pozitive cells in the pancreas islets. We use Ghrelin (H-40) antibody (Santa Cruz-USA), and for the visualization of the results - detection system EnVisionTM FLEX Mini Kit, High Ph (DAKO k8024 HRP). Histomorphometric study performed by Michael Vinther Image Analyzer, Version 1.33 (Mee Soft, Germany).
\end{abstract}

Key words: ghrelin, antibody, bilious epithelium, biliary ducts

\section{INTRODUCTION}

Ghrelin's discovery in 1999 by Kojima et al. (1) opened a new frontier in the understanding of energy homeostasis regulation (2) since ghrelin is the only circulating peptide hormone that stimulates food intake and adiposity in humans (3)

Ghrelin is mainly produced in the stomach from a distinct group of endocrine cells located within the gastric oxyntic mucosa (4). The same authors describe that ghrelin-positive cells are observed along the gastrointestinal tract and pancreas (4).

In the rat ghrelin homologs have been identified in human and other mammalians (1). The ghrelin action is not equal in different animal species. Ghrelin stimulates feeding in rats; however, intracerebroventricular injection of ghrelin strongly suppressed feeding in neonatal chicks (5).

Ghrelin-immunoreactive cells are also found in the duodenum, jejunum, ileum, and colon (6, 7). In the intestine, ghrelin concentration gradually decreases from the duodenum to the colon.

The pancreas is a ghrelin-producing organ. Analyses combining HPLC and ghrelin-RIA revealed that ghrelin and des-acyl ghrelin both exist in the rat pancreas (8). However, the cell type that produces ghrelin in the pancreatic islets remains controversial, whether it be the $\alpha$ cells, $\beta$ cells or the newly identified islet $\varepsilon$ cells. $(8,9)$. Werup et al. investigate the ghrelin regulation of development of novel islet cells in human pancreas (10) and expression of ghrelin in the novel endocrine cells type in rat pancreas islets (11).

The protein $\mathrm{Nkx} 2.2$ is essential for the differentiation of islet $\alpha$ cells and $\beta$ cells, and lack of Nkx2.2 in mice results in replacement of pancreatic endocrine cells by cells that produce ghrelin (9). The role of ghrelin in insulin secretion is under debate. Ghrelin has been shown to inhibit insulin secretion in some experiments and stimulate insulin release in others (12). Some investigators contend that ghrelin of the stomach induces hyperglycemia and reduces insulin secretion in humans (13) but other authors maintain contention that ghrelin presented in pancreatic alpha-cells of humans and rats and stimulates insulin secretion (8). This idea is supported by Lee et al. (14). According to them ghrelin, as a new gastrointestinal endocrine peptide stimulates insulin secretion: enteric distribution, 
ontogeny, influence of endocrine, and dietary manipulations.

According Kojima and Kandawa plasma ghrelin and insulin levels are affected by blood glucose level; high glucose suppresses ghrelin secretion and stimulates insulin secretion (15) and therefore the glucose level in experiments may be important. Date et al. (8) report that ghrelin stimulates insulin release in the presence of high levels of glucose $(8.3 \mathrm{mM})$ but ghrelin had no effect on insulin release in the context of a basal level of glucose (2.8 $\mathrm{mM})$.

\section{AIM AND METHODS}

The aim of this investigation is to localize the ghrelin in the pancreas islets of the rat.

The material was fixed in $4 \%$ aqueous formaldehyde for 48 hours, then embedded in paraffin in accordance with the requirements of $56^{\circ} \mathrm{C}$ standard paraffin inclusion. Using ultramicrotome (Ultracut, Germany) did slice thickness $4 \mu \mathrm{m}$.
For realization of this aim we used an immunohistochemical method. Ghrelin immunoreactivity was determined on sections using Ghrelin (H- 40 ) SC- 50297 Company Santa Cruz, USA. Results visualized with detection system Daco - En Vision FLEX Mini Kit.

\section{RESULTS AND DISCUSSION}

Ghrelin-positive cells are found in some pancreas islets. They are single cells but they are clearly visible (Figure 1). There are many islets without immunoreactive ghrelin cells in a field of vision.

An association between stomach and pancreas obviously manifests that ghrelin immunopositive cell density is lower in the pancreas in comparison with gastric mucosa. This is according to Kojima and Kangawa (15) that was identified ghrelin in the oxyntic gastric mucosa. They described it in highest concentrations in this region.

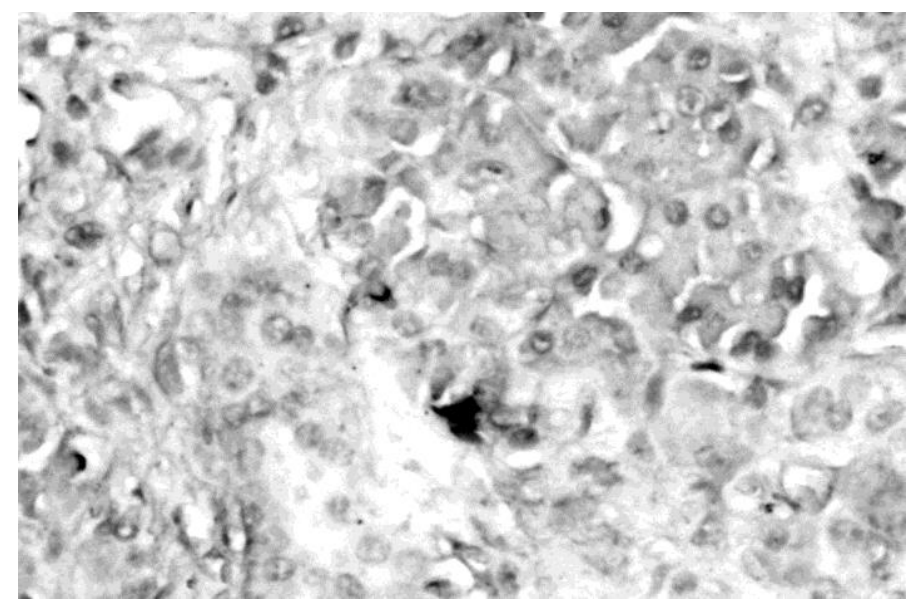

Figure 1. Ghrelin immunoreactive cell in a pancreas islet.

Other authors confirm these results $(6,16)$. Some investigators have reports for expression of ghrelin-positive cells in the rat $(17,18)$ and other authors described a characterization of gastric ghrelin cells in adult and fetal tissues of human and other mammals (19).

\section{CONCLUSION}

Ghrelin-immunoreactive cells are found in all parts of gastrointestinal tract but their quantity is in varying degrees in the different digestive organs. A little some single ghrelin-positive cells are found in pancreas islets.

\section{REFERENCES}

1. Kojima, M, H. Hosoda, Y. Date, M. Nakazato, H. Matsuo, K. Kangawa. Ghrelin is a growth-hormone-releasing acylated peptide from stomach. Nature, 1999, 402: 656-660.
2. Romero, A., H. Kirchner, K. Heppner, P. Pfluger, M. Tscho, R. Nogueiras. GOAT: the master switch for the ghrelin system? European Journal of Endocrinology, 2010, 163: $1-8$.

3. Wren A., C. Small, C. Abbott, W. Dhillo, L. Seal, M. Cohen, R. Batterham, S. Taheri, S. Stanley, M. Ghatei, S. Bloom. Ghrelin causes hyperphagia and obesity in rats. Diabetes, 2001, 50: 2540-2547.

4. De la Cour C, M. Bjorkqvist, A. Sandvik, L. Bakke, C. Zhao, D. Chen, R. Hakanson. A-like cells in the rat stomach contain ghrelin and do not operate under gastrin control. Regulatory Peptides, 2001, 99: 141-150.

5. Furuse, M, T. Tachibana, A. Ohgushi, R. Ando, T. Yoshimatsu, D. Denbow. Intracerebroventricular injection of ghrelin and growth hormone releasing factor 
inhibits food intake in neonatal chicks. Neurosci Lett, 2001, 301: 123-126.

6. Date, Y., M. Kojima, H.Hosoda, A. Sawaguchi, M. Mondal, T. Suganuma, S. Matsukura, K. Kangawa, M. Nakazato, Ghrelin, a novel growth hormone-releasing acylated peptide, is synthesized in a distinct endocrine cell type in the gastrointestinal tracts of rats and humans. Endocrinology, 2000, 141, 4255-4261.

7. Sakata, I., K. Nakamura, M. Yamazaki, M. Matsubara, Y. Hayashi, K. Kangav, T. Sakai. Ghreling-producing cells exist as two types of cells, closed- and opened-type cells, in the rat gastrointestinal tract. Peptides, 2002, 23: 531-536.

8. Date, Y, M. Nakazato, S. Hashiguchi, K. Dezaki, M. Mondal, H. Hosoda, M. Kojima, K. Kangawa, T. Arima, H. Matsuo, T. Yada, S. Matsukura. Ghrelin is present in pancreatic alpha-cells of humans and rats and stimulates insulin secretion. Diabetes, 2002, 51: 124-129.

9. Prado, C, A. Pugh-Bernard, L. Elghazi, B. Sosa-Pineda, L. Sussel. Ghrelin cells replace insulin-producing $\square$ cells in two mouse models of pancreas development. Proc Natl Acad Sci, 2004, USA 101: 2924 2929.

10.Wierup, N, H. Svensson, H. Mulder, F Sundler. The ghrelin cell: a novel developmentally regulated islet cell in the human pancreas. Regul Pept, 2002, 107: 63-69.

11.Wierup, N, S. Yang, R. McEvilly, H. Mulder, F Sundler. Ghrelin is expressed in a novel endocrine cell type in developing rat islets and inhibits insulin secretion from INS-1 (832/13) cells. J Histochem Cytochem, 2004, 52: 301-310.

12. Adeghate, E., A. Ponery. Ghrelin stimulates insulin secretion from the pancreas of normal and diabetic rats. $\mathrm{J}$ Neuroendocrinol, 2002, 14: 555-560.
13. Broglio, F, E. Arvat, A. Benso, C. Gottero, G. Muccioli, M. Papotti, A. van der Lely, R. Deghenghi, E. Ghigo. Ghrelin, a natural GH secretagogue produced by the stomach, induces hyperglycemia and reduces insulin secretion in humans. J Clin Endocrinol Metab, 2001, 86: 5083-5086.

14.Lee, H, G. Wang, E. Englander, M. Kojima, G. Greeley. Ghrelin, a new gastrointestinal endocrine peptide that stimulates insulin secretion: enteric distribution, ontogeny, influence of endocrine, and dietary manipulations. Endocrinology, 2002, 143: 185-190.

15.Kojima, M., K. Kangawa. Ghrelin: Structure and Function. Physiol Rev, 2005, 85: 495-522.

16. Ariyasu, H, K. Takaya, T. Tagami, Y. Ogawa, K. Hosoda, T. Akamizu, M. Suda, T. Koh, K. Natsui, S. Toyooka, G. Shirakami, T. Usui, A. Shimatsu, K. Doi, H. Hosoda, M. Kojima, K. Kangawa, K. Nakao. Stomach is a major source of circulating ghrelin, and feeding state determines plasma ghrelin-like immunoreactivity levels in humans. Journal of Clinical Endocrinology and Metabolism, 2001, 86: 4753-4758.

17.Hamza, S., I. Valkova, D. Sivrev, N. Dimitrov. Grelin-pozitive cells in rats. Scientific Journal of National University of Bioresources and Ecology of Ukraina. Kiev, 2013, 183-187.

18.Hamza, S., I. Vulkuva, M. Gulubova, P. Atanassowa, D. Sivrev. Expression of Ghrelinpositive Cells in the Stomach of the Rat. Acta morphologica et anthropologica, 2015, 21:51-54.

19.Rindi, G, V. Necchi, A. Savio, A. Torsello, M. Zoli, V. Locatelli, F. Raimondo, D. Cocchi, E. Solcia. Characterization of gastric ghrelin cells in man and other mammals: studies in adult and fetal tissues. Histochemistry and Cell Biology, 2002, 117: 511-551. 